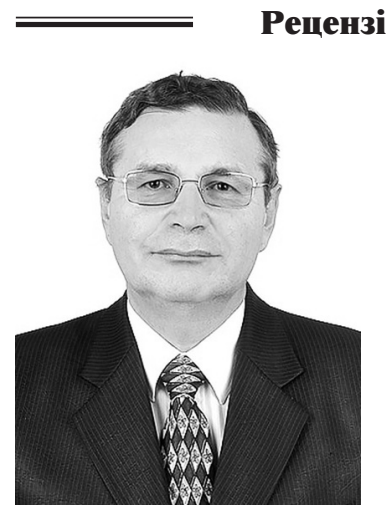

\title{
КНИГА ПРО ФЕНОМЕНАЛЬНУ ОСОБИСТІСТЬ (3 приводу книги Миколи Пугача «Потрібний людям» (Життя видатних людей). Харків: ФОП Панов А.М., 2020. 276 с. іл.)
}

\section{ГРЕЧЕНКО Володимир - доктор історичних Наук, професор, заслужений працівник освіти України}

DOI 10.32782/LAW.2020.2.26

Історики багатьох поколінь зламали чимало списів, дискутуючи про роль особистості в історії. Кожен мислитель намагався дати своєрідне пояснення цьому феномену і тому в науковій літературі нерідко зустрічаються контраверсійні судження. На нашу думку, ця тема ще довго буде актуальною і цікавою для наукової дискусії. I головне тут в усвідомленні та виявленні закономірностей історичного процесу. Абсолютна більшість вчених погоджується з тим, що окремі особистості здійснюють суттєвий вплив на хід історії, але у той же час багато хто 3 них акцентує увагу на тому, що дані особистості лише виконували свою історичну місію, а їхні дії були зумовлені самим ходом історії. Але якими 6 то не були концептуальні побудови чи логічні умовиводи вчених з цього приводу, ясно, що без яскравих особистостей прогрес історії та й саме людське життя неможливі та нецікаві.

В останні десятиліття активно розвивається так звана альтернативна, або контрфактуальна історія, яка відповідає на питання про те, що було б, якби не було тієї чи іншої особистості. Це дає можливість глибше усвідомити та уяснити роль конкретної людини в історичному процесі. Стосовно тієї особистості, про яку йде мова в даній книзі, а саме Олександра Марковича Бандурки, - то цей історичний прийом виглядає дуже доречним та показовим. Поперше, будучи народним депутатом чотирьох скликань, Олександр Маркович конкретно і реально зробив внесок у процес творення незалежної України, прийняття десятків законів. Аише при обговоренні Декларації про державний суверенітет народному депутатові Олександру Бандурці довелося 5 разів виступати з пропозиціями до різних статей. Під час роботи лише Верховної Ради I (XII) скликання О.М. Бандурка взяв участь у розробці 84 законів. Коли відбувалася позачергова сесія Верховної Ради 24 серпня 1991 р. О.М. Бандурка сказав слова, які є актуальними і зараз, майже через 30 років після вказаних подій: «Україна повинна жити власним розумом і Росія нам - не указ».

Значним був внесок Олександра Марковича і у прийняття Конституції України 1996 р. Загалом, в обговоренні проєкту Конституції України у ті червневі дні він виступав 9 разів. Уже цих фактів досить, щоб пишатися ними усе подальше життя. Але ж на цьому державотворча діяльність Олександра Бандурки не закінчилася, вона продовжувалася і далі і навіть сторінок однієї вказаної книги не вистачило для того, щоб описати всю його діяльність у цьому напрямі. Але це не недолік автора книги, у цьому «винна» багатоаспектна, глибинна та результативна діяльність Бандурки-депутата. У цьому один з аспектів його феноменальності та значущості у сучасній історії України. Слід відзначити, що без цього напряму його діяльності усе наше життя і усі наші потуги мали 6 зовсім інший вектор. А тут уже мова йде про долю держави та долю десятків мільйонів ії громадян. Тому 
це одна 3 причин того, чому Олександр Бандурка реально став одним 3 лідерів сучасної епохи в Україні.

По-друге, не було 6 Харківського університету внутрішніх справ, оскільки ідея про його створення та їі втілення цілком є заслугою Олександра Марковича. Я особисто був свідком усіх головних подій, що розгорталися навколо створення університету, і стверджую, що нікому іншому з харків'ян не вдалося $б$ так швидко та результативно здійснити цей задум, у лічені дні юридично оформити створення університету, а далі розширити його матеріальну базу, наповнити його аудиторії сотнями курсантів та викладачів.

По-третє, доля багатьох людей склалася зовсім інакше, якби не зустріч кожного 3 них у певний час з Олександром Марковичем. Причому мова йде, як мінімум, про тисячі людей. Під його науковим керівництвом було захищено 105 докторських та 216 кандидатських дисертацій ( ці цифри досить швидко застарівають через бурхливу наукову діяльність Олександра Бандурки!), чимало людей завдячують йому своїм генеральським званням, почесними званнями «заслужений юрист» чи «заслужений працівник освіти України». У цьому ще один аспект феноменальності Бандурки. Як людина, що багато років займається історією юридичної науки в Україні, я не можу назвати іншого прізвища науковця, який би міг з ним зрівнятися у цій важливій та нелегкій сфері. Звичайно, у таких випадках пишуть «на жаль, не можу». Але думаю, тут доречнішою буде фраза «з задоволенням констатую», оскільки писати про такі успіхи завжди приємно і це викликає і щирий захват, і здивування. Все це має ще й кумулятивний ефект тому, що роботи вченого та його учнів стосуються різних галузей не лише права (що було б не таким феноменальним), але й інших різних сфер науки - тут і психологія, і історія, і політологія, економіка, філософія. Тому й звання академіка Академії правових наук він отримав не за посадою, як це, на жаль, іноді буває, а за конкретні заслуги, як автор близько 500 наукових робіт, більше 100 монографій, підручників, навчальних посібників. Серед них тритомник з історії поліції та міліції в Україні, останній том якого вийшов у 2020 р., «Стратегія і тактика протидії злочинності», «Правова доктрина України» і так далі, i так далі. Прочитав закінчення цього речення і подумав: "Дійсно, знаючи Олександра Марковича, ще буде й далі, й далі, тому що енергії, таланту та завзяття у цієї особистості ще багато і вистачить на цілу наукову лабораторію,чи науковий відділ, який може переважати Олександра Бандурку хіба що в споживанні кави на одну особу та розмовах про науку, а не в ії реалізації». Знову ж таки, автор книги розлого пише про цей аспект діяльності О.М. Бандурки, але не може її всю охопити, що не слід вважати його недоліком, бо для цього треба написати товстезний том

(та, мабуть, не один!) 3 додатками та ілюстраціями. I далі може бути ще по-четверте, і по - п'яте, оскільки діяльність Олександра Марковича цим не вичерпується.

Aле тут виникає ще одне історико- фiлософське питання - у чому корені цього феномену, як він таким став - академіком, генерал-полковником, політичним діячем найвищого рівня. Автор книги справедливо намагається знайти ці корені в родоводі свого героя, житті його предків та природних здібностях. Колись Аюдвіг Бетховен сказав: “Для людини 3 талантом і любов’ю до праці не існує перешкод». Ці слова повною мірою стосуються і Олександра Марковича. Він сам намагався дати відповідь на одвічне питання: «Хто ж формує свою долю - людина особисто чи обставини, в які вона потрапляє?» Про це він пише на сторінках своєї автобіографічної трилогії «Судьба розпорядилась...», що побачила світ 2008 року у видавництві «Золота миля». «У всі часи, - пише О.М. Бандурка, - праця була основним показником не лише фізичних чи розумових, але також моральних цінностей людини. Аише працею можливо реально завоювати авторитет у оточуючих людей i одночасно підняти рівень власного добробуту». Цей вислів можна віднести і до афоризмів видатних людей, визначити як настанову для молодших поколінь, але головне, що в цьому виявляється ще одна риса феноменальності Олександра Бандурки. 


\section{Рецензіі, коментарі}

Працює багато хто і напружено, і чима^о, але результати не такі. Процитуємо ще одного з видатних особистостей - Федора Шаляпіна: «Я взагалі не вірю в одну єдину силу таланту, без наполегливої роботи. Видихається без неї найбільший талант, як затихне в пустелі джерело, що не пробиває собі дороги через піски ...»

Мені довелося неодноразово спілкуватися з Олександром Марковичем і як з політиком, і як з управлінцем, і як з ученим. Завжди він вражав глибиною думки, нетривіальністю суджень, почуттям нового. Його виступи перед аудиторією кожного разу цікаві, насичені афористичністю, гумором, образністю, сильними аргументами. Це може бути аудиторія, що складається 3 професорів або студентів, лише однієї старенької бабці або чарівної студентки. Для усіх він знайде необхідні слова і зможе зацікавити. Він легко побачить і проаналізує «корінь» якоїсь політичної проблеми, швидко визначить рівень наукової дисертації, iї недоліки та шляхи удосконалення, вміє проголосити оригінальний тост та розповісти кумедну бувальщину. Мені доводилося слухати виступи кількох Голів Верховної Ради України, Міністрів внутрішніх справ, відомих юристів та істориків з кращих університетів України. Але такого поєднання різноманітних талантів мені не довелося ще зустрічати, незважаючи, що прожив $\mathrm{i}$ побачив у світі я вже немало.

Видатна риса таланту О.М. Бандурки в тому, що він все життя вчився і ніколи цього не соромився. Наукою, наприклад, почав займатися досить пізно, після 45 років, бо до цього весь час присвячував протидії злочинності. Але швидко догнав і перегнав тих, хто почав займатися нею на 20 років раніше. У цьому теж ще одна особливість цієї особистості. Він завжди прагне до кращого і щоб бути першим. Якщо в спорті - то майстром спорту, якщо в науці - то академіком, якщо в службі - то генералом. Переконаний, що ця його характерна риса багато в чому сприяла досягненню ним різних вершин. Але як людина невгамовна та 3 величезними здібностями, він прагне до нових і нових вершин. Можна бути впевненим, що вони у нього ще попереду, бо його вдача і характер не дозволяють йому довго сидіти на вершині і чекати, поки хтось наблизиться до нього. Хай поспішають на цю вершину, а він піде до іншої!

Автору книги - велика подяка - він намагався показати різнобічність талантів О.М. Бандурки, риси його характеру та його унікальність. Але життя і діяльність Олександра Марковича продовжуються, а це значить, що його нові книги, та книги про нього ще побачать світ. 